\title{
Interactive comment on "Model-driven
} optimization of coastal sea observatories through data assimilation in a finite element hydrodynamic model (SHYFEM v.7_5_65)" by Christian Ferrarin \section{et al.}

\section{Anonymous Referee \#2}

Received and published: 10 November 2020

The comment was uploaded in the form of a supplement:

https://gmd.copernicus.org/preprints/gmd-2020-61/gmd-2020-61-RC3-supplement.pdf

Interactive comment on Geosci. Model Dev. Discuss., https://doi.org/10.5194/gmd-2020-61, 2020. 